\title{
Analisis kemampuan menyelesaikan soal cerita matematika ditinjau dari kemampuan verbal
}

\begin{abstract}
Wahyuddin $^{1}$
Abstrak: Penelitian ini bertujuan untuk mengetahui tingkat kemampuan verbal, kemampuan menyelesaikan soal cerita, dan pengaruh kemampuan verbal terhadap kemampuan menyelesaikan soal cerita matematika pada siswa kelas VII SMP Muhammadiyah SeKota Makassar. Jenis penelitian ini adalah ex-post facto yang bersifat kausalitas dengan populasi siswa kelas VII SMP Muhammadiyah sekota Makassar sebanyak 1048 siswa yang tersebar di 10 sekolah. Sampel diambil sebanyak 145 siswa dengan teknik stratified cluster random sampling. Tes digunakan sebagai instrumen penelitian. Data dianalisis menggunakan statistika deskriptif dan analisis inferensial (Analisis korelasi dan regresi). Hasil penelitian menunjukkan bahwa: (1) Tingkat kemampuan verbal siswa berada pada kategori sedang dengan nilai rata-rata 51,83; (2) Tingkat kemampuan menyelesaikan soal cerita siswa berada pada kategori sedang dengan nilai rata-rata 70,62; (3) Kemampuan verbal memiliki korelasi dengan kemampuan menyelesaikan soal cerita matematika dengan besar hubungan $67,5 \%$; (4) Kemampuan verbal berpengaruh positif terhadap kemampuan menyelesaikan soal cerita dengan pengaruh sebesar $42 \%$ sedangkan sisanya sebesar $58 \%$ dipengaruhi oleh variabel lain. Dengan demikian dapat diartikan bahwa semakin baik atau semakin tinggi kemampuan verbal yang dimiliki oleh siswa maka kemampuan menyelesaikan soal cerita siswa tersebut akan semakin baik atau semakin tinggi.
\end{abstract}

Kata kunci: Kemampuan Verbal; Kemampuan Pemecahan Masalah; Soal Cerita Matematika.

\begin{abstract}
This study aims to determine the level of verbal ability, ability to solve word problems, and the effect of verbal ability toward the ability to solve word problem in grade 7 SMP Muhammadiyah seMakassar. This study is causality ex-post facto with the population of 1048 grade 7 students which spread in 10 schools. The sample is 145 students selected through stratified cluster random sampling method. A test is used as the research instrument. Descriptive and inferential statistics (correlation and regression analysis) are used to analyze data. The results of this study show that: (1) the level of verbal ability is in middle category with average score 51,83 ; (2) the level of ability to
\end{abstract}

${ }^{1}$ Universitas Muhammadiyah Makassar, Indonesia, wahyu@unismuh.ac.id 
solve word problem is in middle category with average score 70,$62 ;$ (3) verbal ability relates to the ability of solving word problem with $67,5 \%$; (4) verbal ability has positive effect toward the ability to solve word problem with influence rate $42 \%$ while the remaining rate $58 \%$ is affected by other variables. In conclusion, the better or the higher the students have verbal ability then the better or the higher the ability of students to solve word problem.

Keywords: Verbal Ability; Mathematics Word Problem; Problem Solving Ability

\section{A. Pendahuluan}

Tujuan pembelajaran matematika yaitu memahami konsep matematika, menggunakan penalaran, memecahkan masalah, mengomunikasikan gagasan dengan simbol, tabel, diagram, atau media lain untuk memperjelas keadaan atau masalah, dan memiliki sikap menghargai kegunaan matematika dalam kehidupan (Wardhani, 2008). Tujuan pembelajaran tersebut dikenal dengan istilah hasil belajar matematika baik dalam bentuk angka atau huruf. Salah satu tolak ukur keberhasilan siswa adalah dengan melihat hasil belajar siswa tersebut, hal ini juga berlaku pada mata pelajaran matematika. Dalam pelajaran matematika untuk memperoleh hasil belajar yang baik dipengaruhi oleh beberapa faktor baik faktor dari dalam (internal) seperti maupun faktor dari luar (eksternal) diri siswa tersebut. Salah satu faktor internal yang harus dipenuhi siswa untuk memperoleh hasil belajar matematika yang baik adalah kemampuan verbal.

Kemampuan verbal diperlukan dalam setiap mata pelajaran, salah satunya matematika. Dalam pembelajaran matematika, kemampuan yang perlu dikuasai siswa tidak terbatas pada kemampuan berhitung saja tetapi juga kemampuan verbal. Hal itu dikarenakan di dalam matematika banyak sekali simbol yang digunakan, baik berupa huruf maupun bukan huruf. Di samping itu, matematika juga tidak bisa dilepaskan dari kegiatan penyelesaian masalah. James dan Adewale (2010) mengemukakan bahwa ada hubungan antara kemampuan pemecahan masalah matematika dan kemampuan verbal siswa. 
Menurut Hidayat (2002), kemampuan verbal adalah kemampuan yang menyangkut pemahaman terhadap ide-ide yang diekspresikan dalam bentuk kata. Manullang (2003) menyatakan bahwa kemampuan verbal adalah kemampuan memahami gagasan dalam bentuk kata-kata. Aspekaspek kemampuan verbal meliputi analogi kata-kata, perbendaharaan kata, dan hubungan kata-kata (Koyan, 2003). Kemampuan verbal seseorang dapat dilihat pada kemampuannya dalam perbendaharaan kata-kata, pembedaan lawan-lawan kata, kemampuan mengisi kalimatkalimat yang tidak lengkap dengan kata-kata yang tepat, menyelesaikan cerita, penafsiran (interpretasi) pepatah-pepatah, membentuk analogianalogi, mengetahui humor-humor dalam karangan-karangan dan mengikuti petunjuk-petunjuk atau instruksi tertulis (Manullang, 2003). Menurut Soeharno (1984) kemampuan verbal penting sekali dalam kegiatan pengajaran dan menentukan keberhasilan seseorang dalam belajar, sebab dengan kemampuan verbal yang tinggi, seseorang dapat mengerti ide serta konsep dan juga dapat dengan mudah berpikir dan memecahkan masalah yang dinyatakan dalam bentuk kata-kata.

Berdasarkan hasil pengamatan yang dilakukan pada Tanggal 14 Maret 2016 di SMP Muhammadiyah I Makassar dan pada Tanggal 15 Maret di SMP Unismuh Makassar diperoleh informasi bahwa kemampuan verbal siswa masih rendah. Hal ini terlihat disaat mereka diberikan soal latihan dalam bentuk verbal atau dalam bentuk masalah nyata. Sebagian kecil siswa yang langsung mengerjakannya sementara sebagian lainnya hanya menunggu jawaban dari teman atau penjelasan guru kemudian menyalinnya. Kurangnya keterampilan dan keaktifan siswa dalam proses pembelajaran terutama dalam menyelesaiakan soal cerita disebabkan berbagai faktor yaitu: siswa kurang menguasai perhitungan, siswa mengalami kesulitan dalam menyelesaikan soal yang ditandai dengan banyaknya kesalahan-kesalahan yang dilakukan siswa dalam menjawab atau mengerjakan soal-soal, dan siswa masih malu dalam mengkomunikasikan gagasannya dan masih ragu-ragu dalam mengemukakan permasalahannya ketika siswa tersebut menghadapi suatu masalah dalam memecahkan persoalan matematika. Ketika ada masalah yang disajikan dalam bentuk lain (tidak sesuai dengan contoh yang diberikan) siswa masih bingung bagaimana menyelesaikannya. Hal ini mencerminkan penalaran siswa dalam proses pembelajaran relatif 
rendah, siswa belum mampu menyampaikan atau mengomunikasikan ide atau pendapatnya. Pendapat yang disampaikan oleh siswa sering kurang terstruktur sehingga sulit dipahami oleh guru maupun temannya.

Soal cerita merupakan permasalahan yang dinyatakan dalam bentuk kalimat bermakna dan mudah dipahami (Wijaya, 2012). Soal cerita dapat disajikan dalam bentuk lisan maupun tulisan, soal cerita yang berbentuk tulisan berupa sebuah kalimat yang mengilustrasikan kegiatan dalam kehidupan sehari-hari (Ashlock, 2003). Soal cerita berguna untuk menerapkan pengetahuan yang dimiliki oleh siswa sebelumnya. Penyelesaian soal cerita merupakan kegiatan pemecahan masalah. Pemecahan masalah dalam suatu soal cerita matematika merupakan suatu proses yang berisikan langkah-langkah yang benar dan logis untuk mendapatkan penyelesaian (Jonassen, 2004). Dalam menyelesaikan suatu soal cerita matematika bukan sekedar memperoleh hasil yang berupa jawaban dari hal yang ditanyakan, tetapi yang lebih penting siswa harus mengetahui dan memahami proses berpikir atau langkah-langkah untuk mendapatkan jawaban tersebut.

Soal cerita matematika sangat berperan dalam kehidupan sehari-hari siswa karena soal tersebut mengedepankan permasalahan-permasalahan yang sesuai dengan kehidupan sehari-hari. Soal cerita sebagai bentuk evaluasi kemampuan siswa terhadap konsep dasar matematika yang telah dipelajari. Seseorang dapat dikatakan memiliki kemampuan matematika apabila terampil dengan benar menyelesaikan soal matematika (Retna, Lailatul, \& Suhartatik, 2013). Dilanjutkan oleh Dewi, Suardjana, dan Sumantri (2014) soal cerita matematika bertujuan agar siswa berlatih dan berpikir secara deduktif, dapat melihat hubungan dan kegunaan matematika dalam kehidupan sehari-hari, dan dapat menguasai keterampilan matematika serta memperkuat penguasaan konsep matematika.

Faktor lain yang harus dipenuhi siswa untuk mendapatkan kemampuan dan hasil belajar matematika yang baik adalah dengan kemampuan menyelesaikan soal cerita. Kemampuan menyelesaikan soal merupakan kemampuan yang dimiliki siswa untuk menyelesaikan soalsoal matematika yang meliputi: (1) kemampuan menuliskan aspek yang diketahui, (2) kemampuan menuliskan aspek yang ditanyakan, (3) kemampuan membuat model matematika, (4) kemampuan 
menyelesaikan model matematika, dan (5) kemampuan menjawab pertanyaan soal (Polya dalam Aisyah, 2007).

Di satu sisi, kemampuan verbal dan kemampuan menyelesaikan soal cerita yang membutuhkan kemampuan pemecahan masalah memiliki peran penting dalam mendukung keberhasilan siswa dalam pembelajaran matematika (Retna, dkk. 2013). Di sisi lain, ada hubungan antara kemampuan pemecahan masalah matematika dan kemampuan verbal siswa (James \& Adewale, 2010). Berdasarkan dua hal tersebut dan hasil observasi di SMP Muhammadiyah terkait kemampuan verbal, penelitian ini bertujuan mengidentifikasi tingkat kemampuan verbal, kemampuan menyelesaikan soal cerita, dan pengaruh kemampuan verbal terhadap kemampuan menyelesaikan soal cerita matematika pada siswa kelas VII SMP Muhammadiyah Se-Kota Makassar.

\section{B. Metode Penelitian}

Penelitian ini termasuk penelitian ex-post facto yang bersifat korelasional. Disebut ex-post facto karena faktor data yang dikumpulkan sudah ada sebelumnya dan bersifat korelasional yaitu mencari hubungan antara variabel. Variabel dalam penelitian ini terdiri dari variabel kemampuan verbal dan variabel dan kemampuan menyelesaikan soal cerita. Populasi dalam penelitian ini adalah seluruh siswa kelas VII SMP Muhammadiyah se-Kota Makassar yang terakreditasi A dan terakreditasi $B$ yang tersebar dalam 10 sekolah. Teknik pengambilan sampel yang digunakan dalam penelitian ini adalah dengan menggunakan stratified cluster proporsional random sampling dimana sampel diambil adalah $50 \%$ dari sekolah yang terakreditasi $A$ atau sebanyak satu sekolah dan $50 \%$ dari sekolah yang terakreditasi B atau sebanyak empat sekolah yaitu lima sekolah secara keseluruhan dimana tiap sekolah diambil satu kelas dengan jumlah sampel sebanyak 145 Siswa.

Dalam upaya mengumpulkan data yang akurat mengenai variabelvariabel yang dikaji, maka dalam penelitian ini menggunakan tes yang berupa serangkaian pertanyaan yang digunakan untuk mengukur hasil kemampuan verbal dan kemampuan menyelesaikan soal cerita pada siswa kelas VII SMP Muhammadiyah Se-Kota Makassar. Untuk memperoleh instrumen penelitian yang benar-benar memenuhi validitas dan reliabilitas atau dapat diandalkan dalam mengungkap data penelitian, 
maka instrumen tes disusun dengan langkah-langkah sebagai berikut: (1) Membuat kisi-kisi tes, (2) menyusun pernyataan untuk skala dan soal tes, (3) divalidasi oleh validator dengan validitas isi (content validity), yaitu ketepatan suatu instrumen ditinjau dari segi materi yang diujikan (untuk tes), (4) uji validitas item dan reliabilitas tes.

Teknik analisis data yang digunakan adalah : (1) Statistika deskriptif yaitu digunakan untuk mendeskripsikan tentang karakteristik distribusi nilai dari masing-masing variabel penelitian seperti rata-rata, standar deviasi dan kriteria yang berdasar penafsiran tentang prestasi kelas; dan (2) analisis infrensial dengan teknik analisis korelasi dan analisis regresi untuk mengetahu pengaruh kemampuan verbal terhadap kemampuan menyelesaiakan soal cerita. Selanjutnya masing-masing variabel diinterpretasikan dalam kategori yang dikemukakan oleh Nurkancana (1983) sebagai berikut.

Tabel 1. Pedoman Interpretasi Variabel Penelitian

\begin{tabular}{|c|c|}
\hline Interval & Kategori \\
\hline $0-30$ & Sangat Rendah \\
\hline $31-54$ & Rendah \\
\hline $55-74$ & Sedang \\
\hline $75-89$ & Tinggi \\
\hline $90-100$ & Sangat Tinggi \\
\hline
\end{tabular}

\section{TEMUAN DAN PEMBAHASAN}

Tabel 2. Hasil Analisis Data

\begin{tabular}{|c|l|c|}
\hline No & \multicolumn{1}{|c|}{ Keterangan } & Nilai \\
\hline 1 & Kemampuan Verbal & 51.83 \\
\hline 2 & Kemampuan Menyelesaikan Soal Cerita & 70.62 \\
\hline 3 & Person Correlation & 0.675 \\
\hline 4 & Sig. & 0.007 \\
\hline 5 & R & 0.665 \\
\hline 6 & R Square & 0.442 \\
\hline 7 & Adjusted R Square 0.420 & 0.420 \\
\hline 8 & F & 23.99 \\
\hline
\end{tabular}

Berdasarkan hasil penelitian diperoleh rata-rata skor kemampuan verbal dari 145 responden sebesar 15,55 berarti sebesar 51,83\% yang berada pada kategori sedang dengan pengklasifikasian kategori yaitu 1 
atau 0,69\% berada pada kategori sangat rendah, 43 atau 26,66\% berada pada kategori rendah,84 atau $57,93 \%$ berada pada kategori sangat sedang, 16 atau $11,03 \%$ berada pada kategori tinggi, dan 1 atau $0.69 \%$ berada pada kategori sangat tinggi.

Skor kemampuan menyelesaikan soal cerita sebesar 70,62 dimana variable tersebut berada pada kategori sedang dengan pengklasifikasian kategori yaitu 2 atau 1,38\% berada pada kategori sangat rendah, 15 atau 10,35\% berada pada kategori rendah, 72 atau 49,66\% berada pada kategori sedang, 51 atau 35,17\% berada pada kategori tinggi, dan 4 atau $3,44 \%$ berada pada kategori sangat tinggi.

Selanjutnya hasil analisis korelasi diperoleh nilai Pearson Correlation sebesar 0,675 dengan nilai sig. $=0.007<0.05$ hal tersebut diartikan bahwa kemampuan verbal memiliki korelasi dengan kemampuan menyelesaikan soal cerita matematika dengan besar hubungan 67,5\% dimana hal tersebut berada pada kategori sedang. Selanjutnya hasil analisis regresi diperoleh nilai $R=0.665$, $R$ Square $=0.442$, Adjusted $R$ Square 0.420 , nilai $\mathrm{F}=23,99$ dengan sig. $=0.007$. hal tersebut dapat diiterpretasikan bahwa nilai $R=0.665, R$ Square $=0.442$, Adjusted $R$ Square 0.420 , nilai $F=23,99$ dengan sig. $=0.007$ menunjukkan bahwa hubungan antara variabel bebas dengan variabel terikat cukup besar yaitu sebesar $44,2 \%$ dengan besar pengaruh variabel kemampuan verbal terhadap kemampuan menyelesaikan soal cerita sebesar $42 \%$ sedangkan sisanya sebesar $58 \%$ dipengaruhi oleh variabel lain di luar model.

Variabel kemampuan verbal dengan rata-rata skor 51.83 dimana nilai tersebut berada pada kategori sedang. Kemampuan verbal terdiri dari empat indikator yaitu sinonim, antonim, padanan kata, dan hubungan kata. Indikator sinonim memiliki nilai $p<0.001<0.05$ yang diartikan bahwa indikator sinonim signifikan atau memiliki kontribusi terhadap variabel kemampuan verbal dengan nilai rata-rata sebesar 55.86 dimana nilai tersebut berada pada kategori sedang. Indikator antonim memiliki nilai $p<0,001<0.05$ yang diartikan bahwa indikator antonim signifikan atau memiliki kontribusi terhadap variabel kemampuan verbal dengan nilai rata-rata sebesar 67.7 dimana nilai tersebut berada pada kategori sedang.

Selanjutnya dari indikator padanan kata memiliki nilai $p<0.001<0.05$ yang diartikan bahwa indikator padanan kata signifikan atau memiliki 
kontribusi terhadap variabel kemampuan verbal dengan nilai rata-rata sebesar 66.03 dimana nilai tersebut berada pada kategori sedang dan indikator hubungan kata memiliki nilai $p<0.001<0.05$ yang diartikan bahwa indikator hubungan kata signifikan atau memiliki kontribusi terhadap variabel kemampuan verbal dengan nilai rata-rata sebesar sebesar 59.43 dimana nilai tersebut berada pada kategori sedang.

Skor kemampuan menyelesaikan soal cerita sebesar 70,62 dimana hal tersebut berada pada kategori sedang. Kemampuan menyelesaikan soal cerita terdiri dari empat indikator yaitu kemampuan menuliskan aspek yang diketahui, kemampuan menuliskan aspek yang ditanyakan, kemampuan menyelesaikan model matematika, dan kemampuan menarik kesimpulan. Indikator kemampuan menuliskan aspek yang diketahui memiliki nilai $\mathrm{p}<0.001<0.05$ yang diartikan bahwa indikator kemampuan menulis aspek yang diketahui signifikan atau memiliki kontribusi terhadap variabel kemampuan menyelesaikan soal cerita dengan nilai rata-rata sebesar 93.40 dimana nilai tersebut berada pada kategori sangat tinggi.

Indikator kemampuan menuliskan aspek yang ditanyakan memiliki nilai $p<0.001<0.05$ yang diartikan bahwa indikator kemampuan menulis aspek yang ditanyakan signifikan atau memiliki kontribusi terhadap variabel kemampuan menyelesaikan soal cerita dengan nilai rata-rata sebesar 69.2 dimana nilai tersebut berada pada kategori sedang. Indikator kemampuan menyelesaikan model memiliki nilai $p<0.001<0.05$ yang diartikan bahwa indikator kemampuan menyelesaikan model matematika signifikan atau memiliki kontribusi terhadap variabel kemampuan menyelesaikan soal cerita dengan nilai rata-rata sebesar 65.3 dimana nilai tersebut berada pada kategori sedang. Dan indikator kemampuan menarik kesimpulan memiliki nilai $\mathrm{p}<0.001<0.05$ yang diartikan bahwa indikator kemampuan kemampuan menarik kesimpulan signifikan atau memiliki kontribusi terhadap variabel kemampuan menyelesaikan soal cerita dengan nilai rata-rata sebesar 52.6 dimana nilai tersebut berada pada kategori rendah.

Selanjutnya dari hasil analisis korelasi diperoleh nilai Pearson Correlation sebesar 0,675 dengan nilai sig. $=0.007<0.05$ hal tersebut diartikan bahwa kemampuan verbal memiliki korelasi/hubungan dengan kemampuan menyelesaikan soal cerita matematika dengan besar hubungan $67,5 \%$ dimana hal tersebut berada pada kategori sedang. Lebih 
lanjut hasil analisis deskriptif dapat dijelaskan bahwa dari 145 siswa terdapat 40 atau $27,59 \%$ siswa yang berada pada kategori tetap yaitu jika kemampuan verbal yang dimiliki berada pada kategori sedang, tinggi, atau sangat tinggi, maka kemampuan menyelesaikan soal cerita yang dimiliki juga berada pada kategori yang sama dengan kemampuan verbalnya; 98 atau 67,59\% siswa yang berada pada kategori meningkat yaitu jika kemampuan verbal yang dimiliki berada pada suatu kategori tertentu, maka kemampuan menyelesaikan soal cerita yang dimilikinya setingkat lebih tinggi dari kemampuan verbalnya; dan 7 atau 4,83\% siswa yang berada pada kategori menurun artinya kemampuan menyelesaikan soal cerita yang dimilikinya akan lebih rendah dari kemapuan verbalnya.

Lebih lanjut kemampuan verbal berpengaruh positif terhadap kemampuan menyelesaikan soal cerita dengan pengaruh sebesar $42 \%$ sedangkan sisanya sebesar $58 \%$ dipengaruhi oleh variabel lain di luar model. Kemampuan verbal berpengaruh positif terhadap kemampuan menyelesaikan soal cerita siswa, hal tersebut dapat diartikan bahwa semakin baik atau semakin tinggi kemampuan verbal yang dimiliki oleh siswa maka kemampuan menyelesaikan soal cerita siswa tersebut akan semakin baik atau semakin tinggi.

Siswa yang memiliki kemampuan untuk memahami hubungan kata, kosa kata, dan menerima dengan cepat kata-kata tertentu berdasarkan informasi atau unsur-unsur yang sudah ada, kemampuan mengingat katakata dan pola yang membentuknya, siswa yang memiliki banyak pengetahuan tentang perbendaharaan kata, memahami persamaan kata (sinonim), memahami lawan kata (antonim), padanan kata, dan hubungan kata, maka maka siswa tersebut akan lebih mudah untuk memanipulasi matematika, mengajukan dugaan, mengembangkan gagasan secara lisan, menarik kesimpulan, dan evaluasi.

Kemampuan verbal merupakan kemampuan untuk menyusun pikiran dengan jelas dan mampu menggunakan kemampuan ini secara kompeten melalui kata-kata untuk mengungkapkan pikiran-pikiran ini dalam berbicara, membaca dan menulis. Azwar (dalam Burhanuddin, 2012) mengatakan bahwa kemampuan verbal yaitu kemampuan untuk memahami hubungan/makna kata, kosakata, dan penguasaan komunikasi lisan lebih lanjut kemampuan verbal adalah kemampuan untuk menyusun pikiran dengan jelas dan mampu menggunakan kemampuan ini secara 
kompeten melalui kata-kata untuk mengungkapkan pikiran-pikiran ini dalam berbicara, membaca dan menulis. Menurut Soeharno (1984), kemampuan verbal penting sekali dalam kegiatan pengajaran dan menentukan keberhasilan seseorang dalam belajar, sebab dengan kemampuan verbal yang tinggi seseorang dapat mengerti ide serta konsep dan juga dapat dengan mudah berpikir dan memecahkan masalah yang dinyatakan dalam bentuk kata-kata. Berdasarkan kedua pendapat di atas terlihat begitu eratnya hubungan antara berpikir dan bahasa.

Berpikir dan bahasa memiliki hubungan erat, karena bahasa berhubungan dengan kemampuan verbal, maka kemampuan verbal pun memiliki hubungan dengan berpikir. Berpikir merupakan suatu aktifitas dalam belajar, sehingga kemampuan verbal pun berhubungan dengan belajar. Pernyataan tersebut didukung oleh pendapat Soeharno (1984) yang menyatakan bahwa kemampuan verbal penting sekali dalam kegiatan pengajaran dan menentukan keberhasilan seseorang dalam belajar, sebab dengan kemampuan verbal yang tinggi, seseorang dapat mengerti ide serta konsep dan juga dapat dengan mudah berpikir dan memecahkan masalah yang dinyatakan dalam bentuk kata-kata.

Hasil penelitian ini sejalan dengan hasil penelitian Yudiani (2014) dengan hasil penelitian bahwa bahwa: (1) terdapat kontribusi kemampuan verbal dalam menyelesaikan soal cerita pelajaran matematika pada siswa kelas 5 Gugus IV Kuta; (2) terdapat kontribusi yang signifikan kemampuan membaca pemahaman terhadap prestasi belajar dalam menyelesaikan soal cerita pelajaran matematika pada siswa kelas 5 SD Gugus IV Kuta; dan (3) terdapat kontribusi yang signifikan kemampuan verbal dan kemampuan membaca pemahaman secara bersama-sama terhadap prestasi belajar siswa dalam menyelesaikan soal cerita pelajaran matematika pada siswa kelas 5 SD Gugus IV Kuta

Penelitian serupa juga dilakukan oleh Wasito (2010) yang menunjukan adanya pengaruh yang positif dan signifikan antara kemampuan penalaran, kemampuan verbal dan kemampuan numerik terhadap kemampuan menyelesaikan soal cerita matematika pokok bahasan aritmetika social. Selain itu, Efendi (2004) juga menyimpulkan bahwa bahwa Kemampuan verbal merupakan salah satu faktor inteligensi yang juga menjadi salah satu faktor penentu keberhasilan siswa dalam berprestasi, terutama kemampuan memahami dan memberikan informasi 
dengan unsur kemampuan verbal yang sangat membantu dalam memahami lambang tulis, lisan, dan gerak berupa kecepatan, kode, operasi verbal. Sementara, usaha untuk mencapai prestasi belajar, tidak terlepas dari ketiga unsur tersebut. Lebih lanjut bahwa ada dua komponen kemampuan verbal ialah (a) pemahaman verbal dan (b) perbendaharan bahasa. Perilaku belajar tidak akan lepas dari dua komponen tersebut, dan oleh karena itu prestasi belajar yang dicapai pelajar tidak akan lepas darikemampuan verbal.

\section{Simpulan}

Berdasarkan hasil penelitian, maka ditarik simpulan sebagai berikut:

1. Tingkat kemampuan verbal siswa berada pada kategori sedang dengan nilai rata-rata 51,83.

2. Tingkat kemampuan menyelesaikan soal cerita siswa berada pada kategori sedang dengan nilai rata-rata 70,62.

3. Tingkat kemampuan verbal memiliki korelasi dengan kemampuan menyelesaikan soal cerita matematika dengan besar hubungan 67,5\% dimana hal tersebut berada pada kategori sedang.

4. Hasil analisis deskriptif diperoleh bahwa terdapat 40 atau $27,59 \%$ siswa yang berada pada kategori tetap yaitu jika kemampuan verbal yang dimiliki berada pada suatu kategori, maka kemampuan menyelesaikan soal cerita yang dimiliki juga berada pada kategori yang sama dengan kemampuan verbalnya. Terdapat 98 atau 67,59\% siswa yang berada pada kategori meningkat yaitu jika kemampuan verbal yang dimiliki berada pada suatu kategori tertentu, maka kemampuan menyelesaikan soal cerita yang dimilikinya akan lebih tinggi dari kemampuan verbalnya. Dan ada 7 atau 4,83\% siswa yang berada pada kategori menurun artinya kemampuan menyelesaikan soal cerita yang dimilikinya akan lebih rendah dari kemapuan verbalnya.;

5. Kemampuan verbal berpengaruh positif terhadap kemampuan menyelesaikan soal cerita dengan pengaruh sebesar $42 \%$ sedangkan sisanya sebesar 58\% dipengaruhi oleh variabel lain di luar model. Kemampuan verbal berpengaruh positif terhadap kemampuan menyelesaikan soal cerita siswa. Hal tersebut dapat diartikan bahwa semakin baik atau semakin tinggi kemampuan verbal yang dimiliki 
oleh siswa maka kemampuan menyelesaikan soal cerita siswa tersebut akan semakin baik atau semakin tinggi.

\section{Ucapan Terima Kasih}

Penulis mengucapkan terima kasih kepada Pimpinan Universitas Muhammadiyah Makassar yang selalau memberi motivasi dan dukungan dalam melaksanakan penelitian sampai pada penyusunan artikel, serta kepala sekolah SMP Muhammadiyah Se-Kota Makassar yang telah memberikan izin untuk melaksanakan penelitian.

\section{Daftar Pustaka}

Aisyah, N. \& Hawa, S. (2007). Pengembangan pembelajaran matematika SD. Jakarta : Direktorat Jenderal Pendidikan Tinggi Departemen Pendidikan Nasional.

Ashlock. (2003). Guiding each child's learning of mathematics. Colombus: Bell Company.

Burhanuddin. (2012). Pengaruh strategi pembelajaran kooperatif dan kemampuan verbal terhadap hasil belajar IPS Siswa MTS Ulumul Qur'an Langsa. Jurnal Tabularasa, PPS Unimed. 9/1, 45 - 62. ISSN : 1693-7732. Diakses di http://digilib.unimed.ac.id/677/1/Fulltext.pdf.

Dewi, S. K., Suardjana., \& Sumantri. (2014). Penerapan model polya untuk meningkatkan hasil belajar dalam memecahkan soal cerita matematika siswa kelas V. Jurnal Mimbar PGSD Universitas Pendidikan Ganesha Jurusan PGSD.

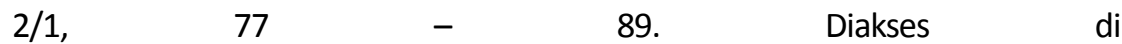
http://ejournal.undiksha.ac.id/index.php/JJPGSD/article/viewFile/4418/3406.

Efendi, K. (2004). Hubungan antara konsep diri dan kemampuan verbal dengan prestasi belajar pada siswa SD Muhammadiyah Sukonandi Yogyakarta. Humanitas : Indonesian Psychologycal Journal. 1/1, 26-31, ISSN: ISSN: 1693-7236. Diakses di http://journal.uad.ac.id/index.php/HUMANITAS.

Hidayat, (2002). Teori dasar intelegensi. Artikel Pendidikan. Diakses di http://kabar-pendidikan.blogspot.co.id/.

James, A.O., \& Adewale, O. A. (2010). Relationship between senior secondary schools students achievement in mathematical problem-solving and intellectual abilities tests. European Scientific Journal. 8/18, 25-53. ISSN: ISSN: 1857-7431. Diakses di http://eujournal.org/index.php/esi/article/view/4724.

Jonassen, D.H. (2004). Learning to solve problem an intsructional design guide. San Fransisco USA: John Wiley \& Sons, Inc. 
Koyan, I.W. (2003). Pengaruh metode pembelajaran kooperatif dan kemampuan penalaran verbal terhadap hasil belajar PPKn. Jurnal Pendidikan dan Pengajaran IKIP Singaraja, 1/XXXVI Januari 2003. Diakses di http://pasca.undiksha.ac.id/images/img item/441.doc

Manullang, M. (2003). Pengaruh penguasaan numerik dan penguasaan verbal terhadap prestasi belajar matematika. Jurnal IImu Pendidikan. 10/2, 163173.

Diakses

di http://id.portalgaruda.org/?ref=browse\&mod=viewarticle\&article=55192.

Nurkancana, W. ( 1983). Evaluasi pendidikan, Surabaya: Usaha Nasional.

Retna, M., Lailatul, M., \& Suhartatik. (2013). Proses berpikir siswa dalam menyelesaikan soal cerita ditinjau berdasarkan kemampuan matematika (The Student Thinking Process in Solving Math Story Problem). Jurnal Pendidikan Matematika STKIP PGRI Sidoarjo . 1/2, 71 82. Diakses di http://www.stkippgri-sidoarjo.ac.id.

Soeharno. (1984). Testologi Pengantar. Jakarta: Bina Aksara.

Wardhani, S. (2008). Paket fasilitasi pemberdayaan KKG/MGMP matematika. Yogyakarta: Pusat Pengembangan Dan Pemberdayaan pendidik dan Tenaga Kependidikan Matematika.

Wasito. (2010). Pengaruh kemampuan penalaran, kemampuan verbal dan kemampuan numerik terhadap kemampuan menyelesaikan soal cerita matematika pokok bahasan aritmetika sosial (Studi Penelitian Pada Siswa Kelas VII Semester Genap SMP Negeri 3 Petarukan). Cakrawala Jurnal Pendidikan UPS Tegal. 4/8, 112-125. Diakses di http://ejournal.upstegal.ac.id/index.php/Cakrawala/index.

Wijaya, A. (2012). Pendidikan matematika realistik: Suatu alternatif pendekatan pembelajaran matematika. Yogyakarta: Graha Ilmu.

Yudiani, N.M., Marhaeni, M., \& Sutama, I.M. (2014). Kontribusi kemampuan verbal dan kemampuan membaca pemahaman terhadap prestasi belajar siswa dalam menyelesaikan soal cerita pada pelajaran matematika, Journal Penelitian Pascasarjana Undiksha. 4/1, 370-380. Diakses di http://pasca.undiksha.ac.id/ejournal/index.php/jurnal pendas/issue/view/68. 